Netherlands and the U.S. while the "very strong smell" and "acrid, pungent taste" (to quote the Oxford English Dictionary) of Allium sativum almost never contribute to the cookery of rural Finland. All around the Mediterranean garlic is used in abundance-in excess Britons might say-and in all that region CHD is far less common than it is in Britain and northern Europe where garlic is used timidly if at all. But there is no lack of other parallel differences between the regions-wine $v$. milk or beer, olive oil $v$. butter, small $v$. large portions of meat, strong $v$. weak coffee or tea, masses of leafy vegetables v. ... you name it.

The development of atherosclerosis and the clinical disease may be promoted or hindered by a host of things, known and unknown, and simple associations, such as those with the use of wine or garlic, warrant no conclusions about cause and effect. At best it might be stated that the observed association is or is not consistent with a certain hypothesis, a hypothesis derived from a reasonable concept of pathogenesis and a clear understanding of relevant facts of physiology and biochemistry. But in regard to wine and garlic the hypothesis is missing.

Most of the differences in the incidence of ischæmic heartdisease among the cohorts of the Seven Countries Study are accounted for by two variables-the concentration of cholesterol in the serum and the arterial blood-pressure. Now if it could be shown that the habit of drinking wine and/or eating garlic lowers the serum cholesterol or the blood pressure, or both, we could urge a campaign to use more wine and garlic. I live much of the time in southern Italy and need no such persuasion happily to embrace the local customs of the kitchen and the dinner table.

Laboratory of Physiological Hygiene,

School of Public Health,

University of Minnesota,

Minneapolis, Minnesota, U.S.A.

Ancel Keys

\section{WHY BLAME CHOLESTEROL?}

SIR, - The correspondence in your Dec. 1 issue again illustrates the fallacy and futility of attempting to attribute unifactorial causality to multifactorial disease. By failing to cite smoking and blood-pressure among the "physical, chemical, organismal, or perhaps immunological" factors involved in the reaction of the vessel wall to injury and subsequent development of cholesterol-containing, raised plaques, Sir John McMichael ignores established fact. He also reveals something of the contrived nature of his contentions by commenting on high mortality in New Zealand Maoris with low cholesterol while omitting any reference to blood-pressure, body-weight, and smoking.

The Report of the Joint Working Party of the Royal College of Physicians and the British Cardiological Society ${ }^{1}$ devoted about a fifth of its content to lipids. It emphasised the variation in CHD risk according to the total burden of risk factors and the need to consider the overall degree of CHD risk rather than whether any particular factor had reached a "critical" level, when dealing with an individual. The same report was unequivocal in stating that the cost of any of the preventive measures recommended, including that of reducing saturated fat and partly substituting polyunsaturated fat, did not approach the cost of inaction.

In our own work in the West of Scotland, ${ }^{2,3}$ the independent and significant nature of the relative and attributable risks in

1. Report of the Joint Working Party of the Royal college of Physicians and British Cardiac Society on Prevention of Coronary Heart Disease, f Roy Coll Phys 1976;10(3): 20.

2. Hawthorne VM, Greaves DA, Beevers DG. Blood pressure in a Scottish town. BrMed f 1974 ; iii: 600 .

3. Hawthorne VM, Greaves DA, Beevers DG. Community studies of hypertension in Glasgow: Epidemiology and control of hypertension. In: Oglesby $P$, ed. Proceedings of second International symposium on the epidemiology of hypertension. Chicago Heart Association, 1975: 537-51. census identified populations of Renfrew and Paisley for CHD mortality by the $80-95$ th and the top 5 th percentile of baseline cholesterol values, has already been described in an illustrative sample of 5616 males observed over 5 years. ${ }^{4}$ No contrary evidence has yet emerged.

Whatever the basis for the $8 \%$ decline and $12 \%$ increase in CHD mortality between 1969 and 1973 in U.S. White males age 45-54 years compared with England and Wales, North Ireland, and Scotland, respectively, ${ }^{5,6}$ cholesterol is one of the many factors contributing in varying degree to this disturbing difference. We hope it will encourage others in U.K. to know that a noteworthy inclusion in the fifteen programmes proposed to prevent disease and promote health into the 1990s in U.S., is one with the specific aim to reduce population cholesterol levels to $180 \mathrm{mg} / \mathrm{dl}$ within this decade. ${ }^{7}$

Department of Epidemiology,

School of Public Health,

University of Michigan,

Ann Arbor, Michigan 48109, U.S.A.

VICTOR M. HAWTHORNE

\section{EXTRA CHROMOSOME 12 IN CHRONIC LYMPHOCYTIC LEUKEMIA}

SIR, - Polyclonal B cell mitogens can induce both DNA synthesis and immunoglobulin production in lymphocytes from patients with chronic lymphocytic leukæmia (CLL). ${ }^{1}$ We have reported that stimulation with one such mitogen, the EpsteinBarr virus (EBV), revealed a chromosomal aberration in a CLL patient. ${ }^{2}$ We have now investigated eight patients with this disease, seven of whom were untreated.

Peripheral blood lymphocytes were stimulated by EBV in all patients. In seven of them another polyclonal B cell mitogen, lipopolysaccharide from Escherichia coli (LPS), was also used for stimulation. Metaphases were analysed after five days of incubation. The Q-banding technique was used for chromosome identification.

Four of the patients had an extra chromosome 12 in more than a third of the metaphases investigated, after stimulation with EBV. Three of them had the same abnormality after stimulation with LPS. Two of these patients had additional aberrations. One had a deletion of chromosome 2 and the other a deletion of chromosome 14 (table).

The conclusion is that polyclonal B cell mitogens can stimulate CLL lymphocytes and reveal previously undetectable

4. Hawthorne VM. Diet and coronary heart disease. Br Med F 1977; ii: 186-87. 5. WHO statistics annual 1969: vol I, vital statistics and causes of death. Geneva: W.H.O., 1972.

6. W.H.O. statistics annual 1973: vol I, vital statıstics and causes of death. Geneva: W.H.O., 1976.

7. Preventing disease/promoting health - objectives for the nation: draft working papers of Atlanta conference. Department of Health Education and Welfare, August, 1979.

1. Robèrt K-H, Bird AG, Möller E. Mitogen-induced differentiation of human CLL lymphocytes to antibody secreting cells. Scand $\mathcal{7}$ Immunol (in press).

2. Gahrton G, Zech L, Robèrt K-H, Bird AG. Mitogenic stimulation of leukemia cells by Epstein-Barr virus. $N$ Engl F Med 1979; 301: 438.

EXTRA CHROMOSOME 12 IN FOUR PATIENTS WITH CLL

\begin{tabular}{|c|c|c|c|c|}
\hline $\begin{array}{l}\text { Age, } \\
\text { sex }\end{array}$ & $\begin{array}{l}\text { WBC } \\
\left(\times 10^{9} / 1\right)\end{array}$ & Mitogen & $\begin{array}{c}\text { Abnormal } \\
\text { metaphases/ } \\
\text { total } \\
\text { metaphases }\end{array}$ & $\begin{array}{l}\text { Chromosomal } \\
\text { abnormality }\end{array}$ \\
\hline $51, \mathrm{~F}$ & 15 & $\begin{array}{l}\text { EBV } \\
\text { LPS }\end{array}$ & $\begin{array}{l}9 / 24 \\
0 / 12\end{array}$ & $\begin{array}{l}+12 \\
\text { Normal }\end{array}$ \\
\hline $49, F$ & 91 & $\begin{array}{l}\text { EBV } \\
\text { LPS }\end{array}$ & $\begin{array}{l}11 / 15 \\
15 / 18\end{array}$ & $\hat{f}+12, \operatorname{del}(2)(\mathrm{q} 31)$ \\
\hline $67, F$ & 32 & $\begin{array}{l}\text { EBV } \\
\text { LPS }\end{array}$ & $\begin{array}{l}6 / 9 \\
9 / 10\end{array}$ & $f+12$, del $(14)(\mathrm{q} 24)$ \\
\hline $78, M$ & 368 & $\begin{array}{l}\text { EBV } \\
\text { LPS }\end{array}$ & $\begin{array}{l}6 / 8 \\
3 / 3\end{array}$ & \}+12 \\
\hline
\end{tabular}

